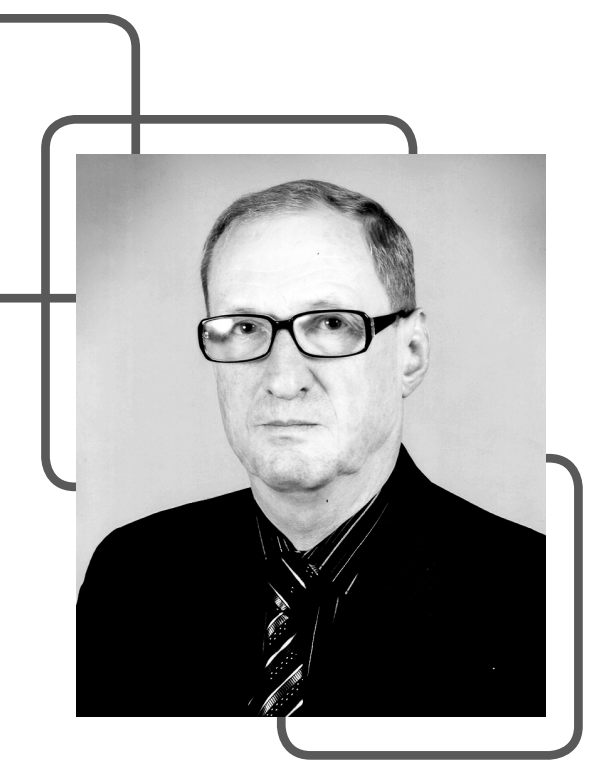

Кормовая добавка, продуктивность коров, качество молока

Supplement, productivity of cows, quality milk
DOI 10.35694/YARCX.2019.46.2.006

\section{ВЛИЯНИЕ ОРГАНИЧЕСКОГО КОМПЛЕКСА НА ПРОДУКТИВНОСТЬ И КАЧЕСТВО МОЛОКА КОРОВ}

\author{
А.И. Фролов (фото) \\ к.С.-х.Н., ведущий научный сотрудник лаборатории \\ технологии производства молока и говядины \\ А.Н. Бетин \\ к.С.-Х.Н., ведущий научный сотрудник лаборатории \\ технологии производства свинины \\ ФГБНУ «Всероссийский научно-исследовательский институт \\ использования техники и нефтепродуктов в сельском \\ хозяйстве», г. Тамбов
}

В молочном животноводстве основой хорошего здоровья животных и получения от них продукции высокого качества является полноценное кормление, но невозможно обеспечить высокую продуктивность коров и её качество без кормовых добавок [1-3]. Впервые в России, на основании исследования, дано практическое обоснование использования в технологии кормления крупного рогатого скота новой отечественной кормовой добавки на основе гидролизата соевого белка, витаминов и микроэлементов в органическом комплексе [4]. Установлено её положительное действие на организм в целом, функции различных органов и систем животных. Экспериментально доказана эффективность её применения для оптимизации обменных процессов.

Задача исследований - повышение экономической эффективности кормления коров с использованием в рационах новой отечественной кормовой добавки с целью увеличения продуктивности и улучшения воспроизводительной функции животных.

Практическая значимость исследований заключается в том, что технология кормления коров на основе оптимизации рационов с применением отечественной кормовой добавки, обладающей высокими биологическими свойствами и изготовленной из недорогих видов сырья, способствует увеличению молочной продуктивности и улучшению воспроизводительных функций у животных.

\section{Результаты исследования}

Изучение эффективности применения в рационах сухостойных и лактирующих животных проводилось на полновозрастных голштинизированных коровах симментальской породы методом групп [5]. Различие в кормлении коров заключалось в том, что животным опытной группы к основному рациону добавляли кормовую добавку 100 мл на 1 голову за три недели до отёла и в течение 30 дней после отёла, которую вносили в корма рациона методом орошения. Рационы удовлетворяли потребность животных в энергии и питательных веществах, в которых на 1 ЭКЕ приходилось 93,6 г переваримого протеина. Уровень сырой клетчатки в 1 кг сухого вещества составил по 18,8\%. Сахаро-протеиновое соотношение было опти- 
мальным для рубцового пищеварения. Основные биохимические показатели крови находились в пределах физиологической нормы. Однако отмечены некоторые особенности у животных опытной группы. Более полное усвоение питательных веществ корма способствовало увеличению содержания некоторых важных для организма компонентов крови. При этом уровень общего белка в сыворотке крови коров опытной группы был выше, чем у контрольных животных (на 2,17\%), что говорит об усилении метаболических процессов в организме животных опытной группы. Об этом также свидетельствует и повышение уровня глюкозы в крови, которое в дальнейшем предполагает сокращение сервис-периода животных.
Продолжительность отделения плаценты у животных опытной группы была достоверно меньше на 1,51 часа по сравнению с контрольной. Заболеваемость кетозом, эндометритом и маститом у контрольных и опытных животных не отмечена. Количество соматических клеток во всех долях вымени у животных обеих групп не

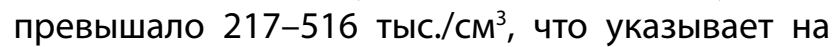
отсутствие субклинических форм мастита. Более высокий уровень обменных процессов стимулировал молочную продуктивность животных опытной группы (табл. 1).

От коров опытной группы получено больше молока за период в сравнении с контрольными на 3570 кг, или на 14,9\% (P < 0,05). Количество мо-

Таблица 1 - Молочная продуктивность коров

\begin{tabular}{|l|c|c|}
\hline \multirow{2}{*}{ Показатель } & \multicolumn{2}{|c|}{ Группа } \\
\cline { 2 - 3 } & контрольная & 27510 \\
\hline Получено молока, кг & 23940 & 3,93 \\
\hline Содержание жира, \% & 3,59 & 1098 \\
\hline Количество молочного жира, кг & 860 & 3,14 \\
\hline Содержание белка, \% & 3,1 & \multicolumn{2}{|c|}{864} \\
\hline Количество белка, кг & 742 & 9,48 \\
\hline \multicolumn{2}{|c|}{ Затраты на 1 кг молока } \\
\hline Обменной энергии, МДж & 10,76 & 0,95 \\
\hline ЭКЕ & 1,07 & 91,0 \\
\hline Переваримого протеина, г & 100,9 & \\
\hline
\end{tabular}

лочного жира и белка, полученных от животных опытной группы, также превышало результат контрольных коров на 238 кг, или на 27\%, по жиру и на 122 кг, или на 16,4\%, по белку соответственно. Затраты кормов на получение 1 кг молока у животных опытной группы были ниже по сравнению с контрольными коровами. В таблице 2 приведены физико-химические показатели молока, из которых видно, что наиболее высокие показатели по содержанию сухого вещества и его ком-

Таблица 2 - Физико-химические показатели молока

\begin{tabular}{|l|c|c|}
\hline \multirow{2}{*}{ Показатель } & \multicolumn{2}{c|}{ Группа } \\
\cline { 2 - 3 } & контрольная & $12,3 \pm 0,06$ \\
\hline Сухое вещество, \% & $12,0 \pm 0,05$ & $8,6 \pm 0,05$ \\
\hline Сухой обезжиренный остаток молока (СОМО), \% & $8,2 \pm 0,03$ & $3,14 \pm 0,03$ \\
\hline Белок, \% & $3,1 \pm 0,01$ & $3,93 \pm 0,04$ \\
\hline Жир, \% & $3,59 \pm 0,03$ & $4,8 \pm 0,006$ \\
\hline Лактоза, \% & $4,8 \pm 0,006$ & $1,030 \pm 0,19$ \\
\hline Плотность, А & $1,029 \pm 0,18$ & $20,0 \pm 0,10$ \\
\hline Кислотность, T & $19,0 \pm 0,09$ & \\
\hline
\end{tabular}


понентов, за исключением лактозы, наблюдались в молоке опытных коров. По этим показателям молоко коров опытной группы отличалось содержанием сухого вещества на 0,3\%, СОМО - на 0,4\%, жира - на 0,34\%, белка - на 0,04\%.
Показатели по эффективности применения кормовой добавки, представленные в таблице 3 , позволили установить, что у коров опытной группы удой на корову за учётные 70 дней лактации составил 1834 кг, что больше аналогичного пока-

Таблица 3 - Экономическая эффективность применения кормовой добавки

\begin{tabular}{|l|c|c|}
\hline \multicolumn{1}{|c|}{ Показатель } & \multicolumn{2}{c|}{ Группа } \\
\cline { 2 - 3 } & контрольная & опытная \\
\hline Удой на 1 корову за учётный период, кг & 1596 & 238 \\
\hline 土к контролю, кг & - & 35 \\
\hline Цена реализации 1 кг молока, руб. & 35 & 64190 \\
\hline Доход от реализации молока, руб. & 55860 & 1200 \\
\hline Израсходовано кормовой добавки, руб. & - & 7130 \\
\hline Получен дополнительный доход, руб. & - & \\
\hline
\end{tabular}

зателя у животных контрольной группы на 238 кг (14,9\%).

\section{Выводы}

1. Включение в рацион высокопродуктивных коров органического комплекса позволило увеличить молочную продуктивность за период на $14,9 \%$ и улучшить физико-химические свойства молока, снизить затраты обменной энергии и переваримого протеина на производство 1 кг молока на 12 и 10\% соответственно.

2. Экономический эффект от применения органического комплекса в дозе 100 мл на 1 гол. лактирующим коровам составил 7130 руб. на 1 животное.

Результаты проведённых исследований указывают на объективную целесообразность использования кормовой добавки коровам из гидролизата соевого белка, витаминов и микроэлементов в заключительном периоде сухостоя, а также в период раздоя с целью повышения продуктивности и качества молока. Органический комплекс позволяет нивелировать погрешности в кормлении, особенно в минерально-витаминной его части.

\section{Лumepamypa}

1. Соколов, А.В. Проблема дисбаланса микроэлементов объемистых кормов [Текст] / А.В. Соколов, С.П. Замана // Кормопроизводство. - 2002. - № 1. - С. 31-32.

2. Волгин, В.И. Оптимизация питания высокоудойных коров [Текст] / В.И. Волгин, Л.В. Романенко, А.С. Бибикова // Животноводство России. - 2005. - № 3. - С. 27-28.

3. Харитонов, Е.Л. Организация научно обоснованного кормления высокопродуктивного молочного скота [Текст]: практические рекомендации / Е.Л. Харитонов. - Боровск: ВНИИФБиП. - 2008. - 106 с.

4. Френк, А.М. Инновационность использования в комбикормовой промышленности гидролизатов растительного белка и микроэлементных препаратов производства ООО Фирма «А-Био» [Текст] / А.М. Френк // Сборник научных трудов МПА. - Выпуск XI. - М., 2013. - С. 58-64.

5. Викторов, П.И. Методика и организация зоотехнических опытов [Текст]: метод. пособие для высш. с.-Х. учеб. заведений / П.И. Викторов, В.К. Менькин. - М.: Агропромиздат, 1991. - 110 с.

\section{References}

1. Sokolov, A.V. Problema disbalansa mikrojelementov ob\#emistyh kormov [Tekst] / A.V. Sokolov, S.P. Zamana // Kormoproizvodstvo. - 2002. - № 1. - S. 31-32.

2. Volgin, V.I. Optimizacija pitanija vysokoudojnyh korov [Tekst] / V.I. Volgin, L.V. Romanenko, A.S. Bibikova // Zhivotnovodstvo Rossii. - 2005. - № 3. - S. 27-28.

3. Kharitonov, E.L. Organizacija nauchno obosnovannogo kormlenija vysokoproduktivnogo molochnogo skota [Tekst]: prakticheskie rekomendacii / E.L. Kharitonov. - Borovsk: VNIIFBiP. - 2008. - 106 s. 
4. Frenk, A.M. Innovacionnost' ispol'zovanija v kombikormovoj promyshlennosti gidrolizatov rastitel'nogo belka i mikrojelementnyh preparatov proizvodstva OOO Firma «A-Bio» [Tekst] / A.M. Frenk // Sbornik nauchnyh trudov MPA. - Vypusk XI. - M., 2013. - S. 58-64.

5. Viktorov, P.I. Metodika i organizacija zootehnicheskih opytov [Tekst]: metod. posobie dlja vyssh. s.-h. ucheb. zavedenij / P.I. Viktorov, V.K. Men'kin. - M.: Agropromizdat, 1991. - 110 s.

\section{ОБЪЯВЛЕHИЕ}

В издательстве ФГБОУ ВО Ярославская ГСХА в 2018 году вышла монография А.И. Голубевой, А.С. Карамышева

\section{«ОБЕСПЕЧЕНИЕ ПРОДОВОЛЬСТВЕННОЙ БЕЗОПАСНОСТИ РЕГИОНА ПО ПРОДУКЦИИ ЖИВОТНОВОДСТВА»}

В монографии содержатся теоретические положения осущности продовольственной безопасности, анализируется состояние обеспеченности пищевыми продуктами населения региона, обосновываются предложения по совершенствованию организационно-экономического механизма обеспечения продовольствием и направлений увеличения объемов производства молочной и мясной продукции до рекомендуемых нормативов. Кроме того, в монографии разработаны и апробированы методические рекомендации по оценке уровня продовольственной безопасности региона с акцентом на вопросы качества потребляемого продовольствия.

Предназначена для научных работников, магистрантов, аспирантов, обучающихся в сельскохозяйственных учебных заведениях, руководителей и специалистов сельского хозяйства.

УДК 636:338.439.5(470.316); ББК 65.32; ISВN 978-5-98914-195-1; 254 стр.

ПО ВОПРОСАМ ПРИОБРЕТЕНИЯ ОБРАЩАТЬСЯ ПО АДРЕСУ:

150042 , г. Ярославль, Тутаевское шоссе, 58, ФГБОУ ВО Ярославская ГСХА

e-mail: e.bogoslovskaya@yarcx.ru 